\title{
PARAMETRIC STABILITY ANALYSIS OF DURUM WHEAT YIELD (TRITICUM DURUM DESF)
}

\author{
Bendjama A. ${ }^{1}$, Solonechnyi P. ${ }^{2}$, Bouzerzour H. ${ }^{3}$, Ramdani S. \\ ${ }^{1}$ University of Skikda, Algeria \\ ${ }^{2}$ Plant Production Institute nd. a V.Ya. Yuriev of NAAS, Ukraine \\ ${ }^{3}$ University of Sétif 1 , Algeria \\ ${ }^{4}$ University of Sidi Bel Abbes, Algeria
}

We evaluated the phenotypic stability of 23 durum wheat genotypes using various stability parameters to select genotypes that have both high performance and stability. The research was conducted in four locations by randomized complete block design with four replications in each location during the 2008-09 and 2009-10 cropping seasons. The objectives were to assess genotype-environment interactions (GEI), determine stable genotypes, and compare the mean grain yield with the stability parameters. To quantify yield stability, seven stability statistics were calculated (bi, Pi, ASVi, CVi, $\mathrm{S}^{2} \mathrm{di}, \mathrm{S}^{2} \mathrm{i}$ and $\mathrm{W}^{2} \mathrm{i}$ ). The grain yields of all genotypes were significantly affected by environment, which accounted for $88.2 \%$ of the total variation, whereas genotype and genotype-environment interaction accounted for $2.9 \%$ and $8.9 \%$, respectively. The genotype mean yield significantly positively correlated with the regression coefficient (bi) and environmental variance $\left(\mathrm{S}^{2} \mathrm{i}\right)$. The correlation analysis also separated the $\mathrm{Pi}$, bi and $\mathrm{S}^{2} \mathrm{i}$ methods, which correlated with the mean yield, and the ASV, $\mathrm{W}^{2} \mathrm{i}$ and $\mathrm{S}^{2}$ di methods, where the phenotypic stability seems to be measured independently on the yield. Genotypes Bel, Amg, Miki, Bss and Msb were more stable by most statistics used. Miki, Amg and Msb were the best genotypes demonstrating high average yields and high stability of performance across the test locations.

\section{Key words: durum wheat, yield, genotype, stability, correlation}

Introduction. Durum wheat (Triticum durum Desf) is an important food crop. This kind of wheat is suitable for production of pasta and spaghetti due to some of its characteristics such as heavy gluten, non-sticky and heavy dough [1]. Developing crop cultivars with high grain yield has been the principal aim of durum wheat breeding programs worldwide [2].

Yield stability has always been considered as an important topic in plant breeding but will be more concern by the continued variation in climatic conditions. The phenotype of an genotype is a mixture of both genotype $(\mathrm{G})$ and environment $(\mathrm{E})$. Genotype-environment (G-E) studies are especially important in countries with various agro-ecologies conditions. For breeders, stability is important from the points of changing genotypes ranks throughout environments and influencing the selection efficiency.

The genotype-environment interactions have been studied by different methods such as estimation of variance components, regression stability parameters [3]. Different concepts and explanations of stability have been described by some of researchers: genotype is considered to be stable if (I) its variance among the environments is small (static or a biological stability), (II) its response to environments is parallel to the mean response of all genotypes in the experiment (dynamic or agronomic stability) or (III) the residual mean square from the regression model on the environmental index is small $[4,5]$.

To study stability of genotypes, several methods have been proposed [4-12]. Some classical stability analysis models such as Finlay and Wilkinson (1963) [7], introduced the coefficient of regression "bi" as a measure of stability in multi-environment trials.

(C) A. Bendjama, P. Solonechnyi, H. Bouzerzour, S. Ramdani 2019. ISSN 1026-9959. Селекція і насінництво. 2019. Випуск 116. 
A genotype with bi<1.0 has above-average stability and is specifically adapted to lowperforming environments; a cultivar with bi>1.0 has below-average stability and is specifically adapted to high-performing environments, while a genotype with $\mathrm{bi}=1.0$ has average stability and is well or poorly adapted to all environments depending on having a high or low mean performance. S.A. Eberhart and W.A. Russell [8] further proposed that both regression coefficient and deviation from linear regression, "S $\mathrm{S}^{2} \mathrm{di}$ ", should be taken into consideration in identifying stable genotypes, and suggested that a genotype with $\mathrm{bi}=1.0$ and $\mathrm{S}^{2} \mathrm{di}=0.0$ may be defined as stable. The AMMI model analysis combines the ANOVA (with additive parameters) and principal component analysis (PCA) into a single analysis [11, 13].

This study was conducted to evaluate the performance of 23 genotypes of durum wheat using various stability parameters to select genotypes that have both high performance and stability.

Material and methods. Trials. The field trials were carried out during the 2008-09 and 2009-2010 cropping seasons at four locations in Algeria. The experimental sites characterized by a climate varying from subhumid to arid, are those of the experimental stations of the Technical Institute of Field Crops of Khroub (36 $\left.26^{\circ} \mathrm{N}, 06^{\circ} 66^{\prime} \mathrm{E}, 713 \mathrm{~m}\right)$, Sétif $\left(36^{\circ} 12^{\prime} \mathrm{N}, 05^{\circ} 24^{\prime} \mathrm{E}, 1023\right.$ $\mathrm{m})$, Guelma ( $\left.36^{\circ} 45^{\prime} \mathrm{N}, 07^{\circ} 47^{\prime} \mathrm{E}, 272 \mathrm{~m}\right)$ and Tiaret $\left(36^{\circ} 05^{\prime} \mathrm{N}, 01^{\circ} 06^{\prime} \mathrm{E}, 1003 \mathrm{~m}\right)$.

Twenty three durum wheat genotypes were tested, including commercial varieties and advanced breeding lines from the national and Cimmyt-Icarda breeding programs (Table 1).

Table 1.

Pedigree and acronym of 23 genotypes tested at the four locations

\begin{tabular}{lc}
\hline \multicolumn{1}{c}{ Pedigree } & Acronym \\
\hline Hoggar check & Vit \\
MBB check & Mbb \\
Boussellem check & Bss \\
Ter-2/3/HFN94-8/Mrb5/Zna-1 ICD00-1090-T-2AP-AP-2AP-TR & Thm \\
Mgnl3/Aghrass2 ICD99-0015-C-9AP-AP-21AP-AP & Mga \\
Adnan-1 ICD00-0866-C-0AP-5AP-AP-8AP-AP & Adn \\
Ter-1/Mrf1/Stj2 & Tms \\
Aghrass-1/HFN94N-8/Mrb5/Zna-1 ICD00-1085-T-2AP-AP-2AP-TR & Amz \\
Aghrass-1/3/Mrf1/Mrb16/Ru ICD00-0834-C-32AP-AP-6AP-TR & Amr \\
Amedakul-1 ICD96-0242-T-2AP-0AP-1AP-AP & Amd \\
Bigost-1 ICD96-0887-C-2AP-0AP-5AP-0AP & Big \\
Mrf1/Stj2/Bcrch1 ICD99-0027-C-0AP-14AP-AP-9AP-AP & Msb \\
Aghrass-1/HFN94N-8/Mrb5/Zna-1 ICD00-1085-T-10AP-AP-10AP-AP & Amz2 \\
Stj2/Dra-2/Bcr/3/Ter-3 & Sdb \\
Beltagy-2 ICD97-0396-T-1AP-AP-5AP-0AP-16AP-AP & Bel \\
Icasyr-1 ICD95-0169-C-0AP-3AP-0AP-5AP-0AP & Ica \\
Azeghar-2/Ch1/F1 13 ICD98-0493-W-AP-2AP-0AP-11AP-AP & Acf \\
Azeghar-1/Blm//Mrf-2 ICD00-0818-C-18AP-AP-9AP-TR & Abm \\
Miki-3 ICD94-0994-C-10AP-0AP-2AP-0AP-9AP-0TR & Miki \\
Azeghar-1/3/Mrf-2/Bcr/Gro-1 ICD00-0904-H-9AP-AP-1AP-TR & Amg \\
Ter-1/3/Stj3/Bcr/Lks-4 ICD99-1036-T-0AP-7AP-AP-3AP-AP & Tsb \\
Ammar-2 ICD94-0918-C-12AP-0AP-6AP-0AP-3AP-0AP & Amm \\
Aghrass-1/3/HFN94N-8/Mrb5/Zna-1 ICD00-1065-T-4AP-AP & Amz3 \\
\hline
\end{tabular}

These genotypes were sown in a randomised complete block design with four replications. The experiments were conducted under rainfed conditions.

Stability analysis. Stability analysis is approximated by the computation of the slope value (bi) and deviation from regression $\left(\mathrm{S}^{2} \mathrm{di}\right)$ [8], ecovalence $\left(\mathrm{W}^{2} \mathrm{i}\right)$ [6], the index of the genotypic superiority $\left(\mathrm{P}_{\mathrm{i}}\right)$ [4], the environmental variance $\left(\mathrm{S}^{2} \mathrm{i}\right)$ [5], the coefficient of variability (CVi) [9] and the stability value AMMI (ASVi) described by J.L. Purchase et al., 2000 [12]. 
The Spearman correlation coefficient was calculated for each pair of possible pairwise comparison of the stability parameters.

The data on yields were mathematically processed using Genstat 12 software.

Result and discussion. The mean performance of the tested genotypes across the testing years and locations ranged from 3.12 tha $^{-1}$ for Mbb to 4.52 tha $^{-1}$ for Miki. The mean yield of the testing environments varied from 1.73 tha $^{-1}$ for Tiaret 2008/09 to 6.55 tha $^{-1}$ for Khroub 2008/09 indicating, the influence of soil, temperature, precipitation, etc. on the yield.

Combined analysis of variance showed that there were highly significant differences for the environments, genotypes and their interactions. The results of combined analysis of variance are shown in Table 2 . In our study, the durum wheat grain yields were significantly affected by the environment, which accounted for $88.2 \%$ of the total $(\mathrm{G}+\mathrm{E}+\mathrm{GE})$ variation, whereas genotype and genotype-environment interaction accounted for $2.9 \%$ and $8.9 \%$, respectively. A large sum of squares for environments indicated that the environments were diverse, with large differences between the environmental means causing variation in the grain yields. In most multienvironment trials the environment account for over $80 \%$ of the total variation $[14,15,16]$.

Table 2.

Analyses of variance of the grain yield of 23 durum wheat genotypes in 8 environments

\begin{tabular}{lccccc}
\hline \multicolumn{1}{c}{ Source } & DF & SS & MS & G+E+GE SS (\%) & GE SS (\%) \\
\hline Genotypes (G) & 22 & 55,3 & $2,51^{* *}$ & 2.9 & \\
Environments (E) & 7 & 1640.9 & $234.41^{* *}$ & 88.2 & \\
Block & 24 & 27.9 & 1.16 & & \\
Interactions (GE) & 154 & 167.6 & $1.09^{* *}$ & 8.9 & 48.7 \\
IPCA1 & 28 & 81.6 & 2.91 & & 15.0 \\
IPCA2 & 26 & 25.2 & 0.97 & & 10.7 \\
IPCA3 & 24 & 24.3 & 1.01 & \\
IPCA4 & 22 & 18.0 & 0.82 & \\
Residuals & 54 & 18.4 & 0.34 & \\
Error & 528 & 288.5 & 0.55 & & \\
Total & 735 & 2180.1 & 2.97 & & \\
\hline
\end{tabular}

$\mathrm{DF}=$ degree of freedom; $\mathrm{SS}=$ sum of squares; MS = mean square; $* *$ significant at $1 \%$.

The part of each environment in the $\mathrm{G} \times \mathrm{E}$ interaction has been estimated through the environmental ecovalence $\left(\mathrm{W}^{2} \mathrm{i}\right)$. Ecovalence is a measure of the contribution of environment and genotype to interaction. An environment with a high ecovalence contributes more to the interaction. Indeed, the Khroub site is the most interactive in the two companions followed by the Guelma site as a first companion and the Tiaret site in the second, the Setif site of the first season contributes little to the interaction (Figure 1).

Ecovalence $\left(\mathrm{W}^{2} \mathrm{i}\right)$ is also a measure of a contribution of the genotype to the genotype $\mathrm{x}$ environment interaction. A value $\mathrm{W}^{2} \mathrm{i}$ of zero or close to zero is indicative of stability. High values $\mathrm{W}^{2} \mathrm{i}$ are indicative of instability. A genotype with the least ecovalence is considered the ideal from the point of view of yield stability. Genotype MBB with high ecovalence and was the most unstable, followed by Tsb and Amr (Table 4). Genotype Bel with above average grain yield is characterized by the lowest $\mathrm{W}^{2} \mathrm{i}$ suggesting that this genotype is the most stable given its weak contribution to the interaction. Among the high-performance genotypes Amg, Miki, Bss and Msb are moderately interactive, and therefore relatively stable.

The use of this stability parameter in plant breeding requires determining the weight to be given to the stability, relative to the yield potential, under semi-arid conditions as farmers are looking for varieties whose performance is stable in the face of interannual variation of climate. This is the case of genotype Amg with $\mathrm{W}^{2} \mathrm{i}=0.86$, which appears to be the desired genotype. 


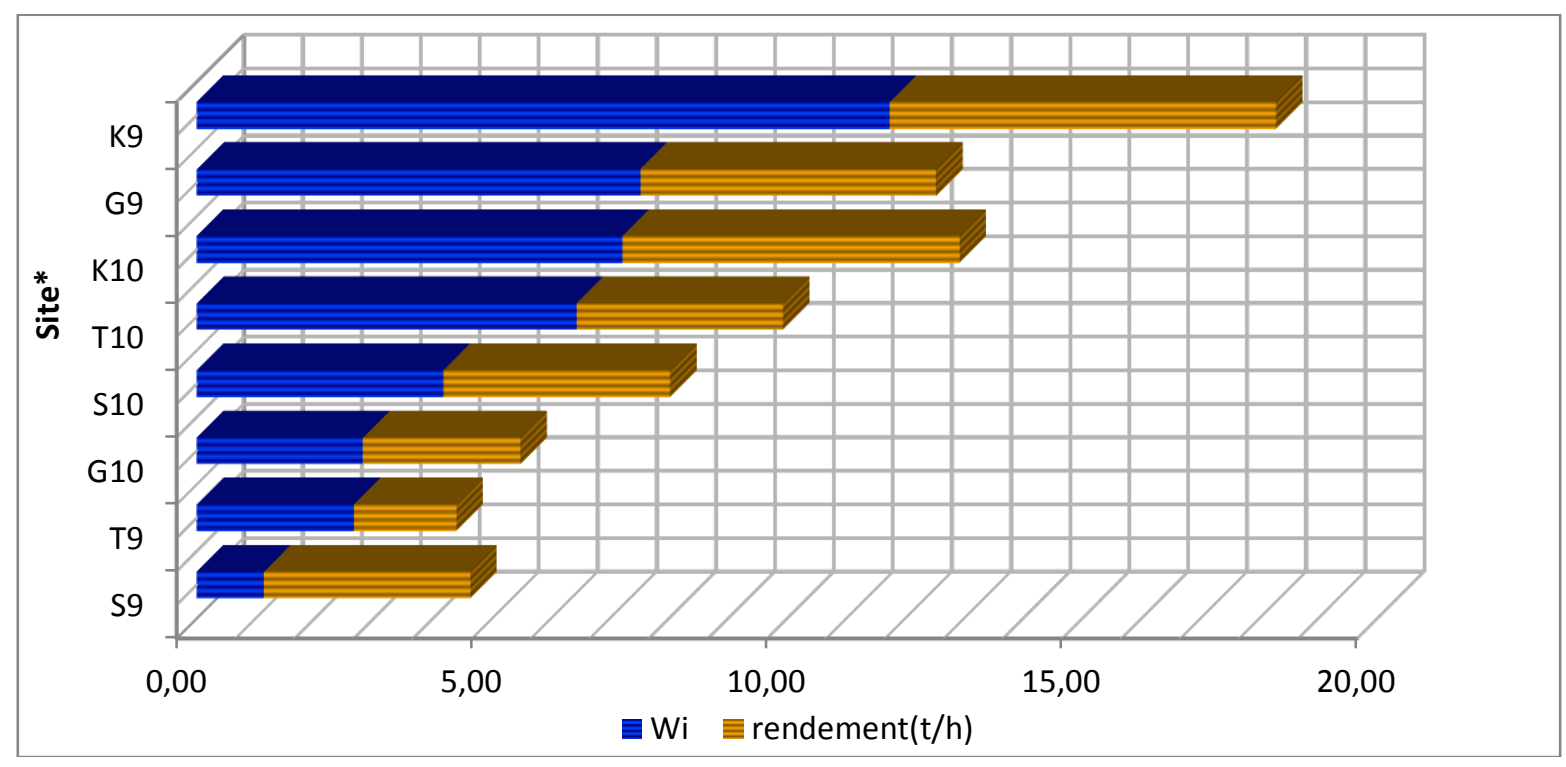

* K9 and K10 - Khroub 2008-09 and 2009-10 cropping seasons, respectively; G9 and G10 - Guelma 200809 and 2009-10 cropping seasons, respectively; T9 and T10 - Tiaret 2008-09 and 2009-10 cropping seasons, respectively; S9 and S10 - Sétif 2008-09 and 2009-10 cropping seasons, respectively.

Figure 1. Average yield and environmental ecovalence calculated for the four experimental sites in two farming seasons

Table 3.

Mean yield and stability parameters of the 23 durum wheat genotypes evaluated at four experimental sites in two farming seasons

\begin{tabular}{lcccccccc}
\hline Genotype & Yield (tha $\left.{ }^{-\mathbf{1}}\right)$ & $\mathbf{b i}$ & $\mathbf{S}^{\mathbf{2}} \mathbf{d i}$ & $\mathbf{P i}$ & $\mathbf{S}^{\mathbf{2}} \mathbf{i}$ & $\mathbf{W}^{\mathbf{2}} \mathbf{i}$ & $\mathbf{A S V i}$ & $\mathbf{C V i} \mathbf{\%}$ \\
\hline Vit & 3.92 & 0.967 & -0.002 & 0.679 & 2.45 & 0.53 & 0.202 & 39.94 \\
Mbb & 3.12 & 0.362 & -1.206 & 2.664 & 0.96 & 11.6 & 2.650 & 31.39 \\
Bss & 4.36 & 0.968 & -0.001 & 0.273 & 2.54 & 1.07 & 0.350 & 36.56 \\
Thm & 3.70 & 0.822 & -0.092 & 1.107 & 1.94 & 2.09 & 0.727 & 37.57 \\
Mga & 4.15 & 1.156 & -0.071 & 0.426 & 3.46 & 0.84 & 0.586 & 44.80 \\
Adn & 4.12 & 1.114 & -0.037 & 0.430 & 3.24 & 0.81 & 0.251 & 43.74 \\
Tms & 3.88 & 1.038 & -0.003 & 0.769 & 2.90 & 1.19 & 0.659 & 43.87 \\
Amz & 3.94 & 0.883 & -0.039 & 0.711 & 2.24 & 1.47 & 0.368 & 37.59 \\
Amr & 4.12 & 1.221 & -0.143 & 0.608 & 4.12 & 3.16 & 0.992 & 49.26 \\
Amd & 4.17 & 1.005 & 0.002 & 0.495 & 2.73 & 1.08 & 0.344 & 39.65 \\
Big & 4.01 & 1.058 & -0.008 & 0.605 & 3.03 & 1.39 & 0.765 & 43.43 \\
Msb & 4.35 & 1.196 & -0.112 & 0.270 & 3.71 & 1.21 & 0.653 & 44.32 \\
Amz2 & 4.09 & 1.114 & -0.037 & 0.490 & 3.22 & 0.65 & 0.436 & 43.88 \\
Sdb & 3.87 & 0.958 & -0.004 & 0.711 & 2.38 & 0.39 & 0.075 & 39.88 \\
Bel & 4.11 & 1.056 & -0.008 & 0.426 & 2.88 & 0.34 & 0.261 & 41.28 \\
Ica & 4.20 & 1.082 & -0.018 & 0.404 & 3.08 & 0.83 & 0.269 & 41.79 \\
Acf & 4.03 & 0.964 & -0.002 & 0.668 & 2.77 & 2.90 & 0.972 & 41.25 \\
Abm & 4.21 & 1.031 & -0.001 & 0.369 & 2.92 & 1.51 & 0.477 & 40.59 \\
Miki & 4.52 & 1.023 & 0.000 & 0.196 & 2.87 & 1.51 & 0.248 & 37.46 \\
Amg & 4.36 & 1.161 & -0.075 & 0.257 & 3.49 & 0.86 & 0.482 & 42.84 \\
Tsb & 4.28 & 0.918 & -0.018 & 0.476 & 2.69 & 3.93 & 1.313 & 38.31 \\
Amm & 4.07 & 1.115 & -0.038 & 0.529 & 3.33 & 1.42 & 0.812 & 44.85 \\
Amz3 & 3.76 & 0.788 & -0.132 & 1.004 & 1.88 & 2.91 & 0.945 & 36.43 \\
Mean & 4.06 & & & & & & & \\
LSD 05 & 0.37 & & & & & & & \\
\hline & & & & & & & &
\end{tabular}


The regression coefficient bi changed between 0.362 for Mbb and 1.221 for Amr. The analysis of the individual regression slopes of the genotypes indicates that lines Msb and Amg have bi values significantly higher than 1 . These varieties have grain yields higher than the overall average and a specific adaptation to environments with high production potential known as "favorable environments". The regression coefficient of Mbb is significantly lower than 1, this genotype is specified by grain yield lower than the overall average of the experiment and a specific adaptation to the environments at low grain yield potential. A regression coefficient significantly lower than 1 indicates greater resistance to environmental variation, which induces stability above the average stability of all the genotypes tested. The slopes of the remaining entrances are not significantly different from 1, suggesting average stability. Most of these genotypes have grain yields higher than the overall average $\left(4.06\right.$ tha $\left.^{-1}\right)$, and thus these genotypes have a general adaptation in all environments.

On the basis of the residual of the regression $\left(\mathrm{S}^{2} \mathrm{di}\right)$, we note that genotype Miki has $\mathrm{S}^{2} \mathrm{di}=0$, this genotype has, therefore, high biological stability, the other high-performance genotypes such as Bss, Amd and Abm have a $S^{2}$ di close to zero. According to N. Sabaghnia et al. (2006) [17], the ideal genotype is the one with the highest grain yield associated with a regression coefficient that does not deviate significantly from 1 , and $S^{2}$ di value of zero or close to zero. Among the genotypes evaluated in this study, only Miki is close to this definition. Genotype MBB is the most unstable.

Genotype superiority index $\mathrm{Pi}$ is a joint measure of yield potential and stability [18]. This index measures the distance between the performance of the genotype of interest and the best performance achieved in the given environment. L.W. Rose et al. (2008) [19] mention that the low values of Pi are the most desirable in selection because they are characteristic of efficient and stable genotypes. Pi values range from 0.19 for Miki to 2.66 for Mbb. Genotypes Miki, Msb and Bss are classified as high performance and stable. Conversely, Mbb and Amz3 are unstable and low yielding.

The results of the CV stability parameter showed little difference, genotype Mbb is the most stable with a CV of $31.39 \%$ and Amr is unstable with highest CV value of $49.26 \%$.

The environmental variance $\left(\mathrm{S}^{2} \mathrm{i}\right)$, which describes the biological stability, quantitatively reflects the yield of a genotype in all environments; based on this index, genotypes Mbb, Amz3 and Thm are the most stable and have biological stability but low performance. Amr and Mga have high performance and are unstable, while genotypes Miki, Bss and Tsb are high yielding and moderately stable.

The AMMI stability value (ASVi) ranked genotype Sdb with the lowest value (ASVi = 0.075), as the most stable although it obtained a low yield $\left(3.87 \mathrm{tha}^{-1}\right)$, and ranked Mbb with the highest ASVi (2.65) as the most unstable. Miki which records a low value (ASVi $=0.248$ ) had the highest yield, suggests that this genotype is the most stable among the high-performance genotypes and, therefore, the most suitable for the testing environments, which explains its position at the top of the ranking in several sites. The other high-performance genotypes, namely, Tsb, Amg and Msb have high yields but relatively unstable due to their large ASV values (1.313, 0.653 and 0.482 ).

Analysis of Spearrman rank correlation coefficients (Table 4) indicates that the linkages identified in this study are similar to those reported by M. Ackura et al. (2006) [20], R. Mohammadi et al. (2010) [21], E. Farshadfar and N. Hatami (2015) [22].

The mean grain yield of a genotype significantly positively correlated with the regression coefficient (bi) $(\mathrm{r}=0.521 *)$ and environmental variance $\left(\mathrm{S}^{2} \mathrm{i}\right)\left(\mathrm{r}=0.543^{* *}\right)$, indicating that high grain yielding genotypes had higher of bi and $\mathrm{S}^{2} \mathrm{i}$. Conversely, the mean grain yield weakly correlated with the other stability parameters. Selection for increased yield in durum wheat would, therefore, be expected to change yield stability by increasing bi and $S^{2}{ }^{2}$. Since the regression coefficient represents adaptation of a genotype to various environments, genotypes with higher regression coefficient could be adapted to more favorable environments and achieve better yield performance. Genotypes with lower regression coefficients tended to have lower yields and were more adaptable to unfavorable environments. 
Table 4.

Spearman rank coefficients (rs) between the mean yield and stability parameters

\begin{tabular}{|c|c|c|c|c|c|c|c|}
\hline Variables & Yield & bi & $\mathrm{Pi}$ & ASVi & $\mathrm{Wi}^{2}$ & $\mathrm{~S}^{2} \mathrm{i}$ & $\mathrm{CVi}$ \\
\hline bi & $0.521 *$ & & & & & & \\
\hline $\mathrm{Pi}$ & $-0.943 * * *$ & $-0.591 * *$ & & & & & \\
\hline ASVi & -0.236 & -0.081 & 0.375 & & & & \\
\hline $\mathrm{Wi}^{2}$ & -0.114 & -0.365 & 0.317 & $0.787 * * *$ & & & \\
\hline $\mathrm{S}^{2} \mathrm{i}$ & $0.543 * *$ & $0.982 * * *$ & $-0.590 * *$ & 0.025 & -0.249 & & \\
\hline $\mathrm{CVi}$ & 0.183 & $0.890 * * *$ & -0.249 & 0.079 & -0.322 & $0.898 * * *$ & \\
\hline $\mathrm{S}^{2} \mathrm{di}$ & 0.298 & -0.142 & -0.297 & $-0.542 * *$ & -0.315 & -0.154 & -0.193 \\
\hline
\end{tabular}

The Pi index shows the largest deviation from all the other methods, without strong positive rank correlation coefficients with other indices and negatively correlated with the mean yield, bi and $\mathrm{S}^{2} \mathrm{i} . \mathrm{S}^{2} \mathrm{i}$ positively correlated with the average yield and bi and negatively with $\mathrm{Pi}$. $\mathrm{S}^{2} \mathrm{i}$ also strongly correlated with $\mathrm{CVi}(\mathrm{r}=0.898, \mathrm{P}<0.001)$, these two indices ranking genotypes in a similar way. Suggesting their strong relationship in detection of stable genotypes. CVi positively correlated with the regression coefficient (bi) and environmental variance $\left(\mathrm{S}^{2} \mathrm{i}\right)$. ASV correlated with Wricke's $\left(\mathrm{W}^{2} \mathrm{i}\right)$ ecovalence and $\mathrm{S}^{2} \mathrm{di}$, these three stability statistics do not correlate to the average yield.

The correlation analysis, therefore, separated the $\mathrm{Pi}$, bi and $\mathrm{S}^{2} \mathrm{i}$ methods, which correlated with the mean yield, and the ASV, $\mathrm{W}^{2} \mathrm{i}$ and $\mathrm{S}^{2}$ di methods, where the phenotypic stability seems to be measured independently of the yield.

Conclusions. In summary, durum wheat genotypes Bel, Amg, Miki, Bss and Msb were the most stable by the most statistics used. The correlation analysis separated the $\mathrm{Pi}$, bi and $\mathrm{S}^{2} \mathrm{i}$ methods, which correlated with the mean yield, and the ASVi, $\mathrm{W}^{2} \mathrm{i}$ and $\mathrm{S}^{2}$ di methods, where the phenotypic stability seems to be measured independently of the yield. The mean grain yield of a genotype significantly positively correlated with the regression coefficient (bi) and environmental variance $\left(\mathrm{S}^{2} \mathrm{i}\right)$. Therefore, selection for increased yield in durum wheat would be expected to change yield stability by increasing bi and $\mathrm{S}^{2} \mathrm{i}$.

Acknowledgements. We would like to thank the ITGC stations of Kroub, Sétif, Guelma and Tiaret (Algéria) for providing necessary facilities to conduct the trials.

\section{References}

1. Sissons MJ. Role of durum wheat composition on the quality of pasta and bread. Global Science Books, 2008. P. 75-90.

2. Mohammadi M, Sharifi P, Karimizadeh R. Stability Analysis of durum wheat genotypes by regression parameteres in dryland conditions. Acta Universitatis Agriculturae et Silviculturae Mendelianae Brunensis. 2014; 62(5): 1049-1056. DOI: 10.11118/actaun201462051049.

3. Akcura M, Kaya Y, Taner S. Genotype-environment interaction and phenotypic stability analysis for grain yield of durum wheat in the Central Anatolian Region. Turkish J. Agric. Fores. 2005; 29: 369-375.

4. Lin CS, Binns MR, Lefkovitch LP. Stability analysis: Where do we stand? Crop Sci. 1986; 26: 894-900.

5. Becker HC, Leon J. Stability analysis in plant breeding. Plant Breeding. 1988; 101: 1-23.

6. Wricke G. On a method of understanding the biological diversity in field research. Z. Pfl.Zücht. 1962; 47: 92-146.

7. Finlay KW, Wilkinson GN. The analysis of adaptation in a plant breeding programme. Australian J. Agric. Res. 1963; 14: 742-754.

8. Eberhart SA, Russel WA. Stability parameters for comparing varieties. Crop Sci. 1966; 6: $36-40$. 
9. Francis TR, Kannenberg LW. Yield stability studies in short-season maize. i. a descriptive method for grouping genotypes. Revue Canadienne de Phytotechnie. 1978; 58(4): 10291034. DOI: $10.4141 /$ cjps 78-157.

10. Becker HC. Correlation among some statistical measures of phenotypic stability. Euphytica. 1981; 30(3): 835-884.

11. Gauch HG, Zobel RW. AMMI analysis of yield trials. Chap. 4. In: Kang, M.S. \& Gauch H.G., (Eds.), Genotype by environment interaction. CRC Press, Boca Raton, FL, USA. 1996. P. 85-122.

12. Purchase JL, Hatting H, van Deventer CS. Genotype $x$ environment interaction of winter wheat in south Africa : II. Stability analysis of yield performance. South African Journal of Plant and Soil. 2000; 17:101-107. DOI: 10.1080/02571862.2000.10634878.

13. Gauch HG. Statistical analysis of yield trials by AMMI and GGE. Crop Science. 2006; 46(4): 1488-1500.

14. Yan W. Singular-value partitioning in biplot analysis of multi-environment trial data. Agronomy Journal. 2002; 94: 990-996. DOI: 10.2134/agronj2002.9900.

15. Yan W, Kang MS. GGE biplot analysis: a graphical tool for breeders, geneticists and agronomists. Boca Raton, USA, 2003.

16. Gauch HGJr, Piepho PH, Annicchiarico P. Statistical analysis of yield trials by AMMI and GGE: further considerations. Crop Science. 2008; 48: 866-889.

17. Sabaghnia N, Dehghani H, Sabaghpour SH. Nonparametric methods for interpreting GxE interaction of lentil genotypes. Crop Sci. 2006; 46: 1100-1106.

18. Lin CS, Binns MR. A superiority measure of cultivar performance for cultivar $\mathrm{x}$ location data. Can. J. Plant Sci. 1988; 68: 193-198.

19. Rose LW, Das MK, Taliaferro CM. A comparison of dry matter yield stability assessment methods for small numbers of genotypes of Bermudagrass. Euphytica. 2008; 164; 19-25. DOI: $10.1007 / \mathrm{s} 10681-007-9620-2$.

20. Akcura M, Kaya Y, Taner S, Ayranci R. Parametric stability analyses for grain yield of durum wheat. Plant Soil Environ. 2006; 52 (6): 254-261.

21. Mohammadi R, Roostaei M, Ansari Y, Aghaee M, Amri A. Liens entre la mesure de la stabilite du phenotype et le genotype de trois cereals. Can. J. Plant Sci. 2010; 90: 819-830. DOI: $10.1139 /$ CJPS2013-386

22. Farshadfar E, Hatami N. Evaluation of Genotype $\times$ Environment Interaction in Wheat Substitution Lines. Agricultural Communications. 2015; 3(1): 1-7.

\section{Список використаних джерел}

1. Sissons M.J. Role of durum wheat composition on the quality of pasta and bread. Global Science Books, 2008. P. 75-90.

2. Mohammadi M., Sharifi P., Karimizadeh R. Stability Analysis of durum wheat genotypes by regression parameteres in dryland conditions. Acta Universitatis Agriculturae et Silviculturae Mendelianae Brunensis. 2014. № 62(5). P. 1049-1056. DOI: 10.11118/actaun201462051049.

3. Akcura M., Kaya Y., Taner S. Genotype-environment interaction and phenotypic stability analysis for grain yield of durum wheat in the Central Anatolian Region. Turkish J. Agric. Fores. 2005. № 29. P. 369-375.

4. Lin C.S., Binns M.R., Lefkovitch L.P. Stability analysis: Where do we stand? Crop Sci. 1986. № 26. P. 894-900.

5. Becker H.C., Leon J. Stability analysis in plant breeding. Plant Breeding. 1988. № 101. P. 123.

6. Wricke G. On a method of understanding the biological diversity in field research. Z. Pfl.Zücht. 1962. № 47. P. 92-146.

7. Finlay K.W., Wilkinson G.N. The analysis of adaptation in a plant breeding programme. Australian J. Agric. Res. 1963. № 14. P. 742-754.

8. Eberhart S.A., Russel W.A. Stability parameters for comparing varieties. Crop Sci. 1966. № 6. P. 36-40. 
9. Francis T.R., Kannenberg L.W. Yield stability studies in short-season maize. i. a descriptive method for grouping genotypes. Revue Canadienne de Phytotechnie. 1978. № 58(4). P. 10291034. DOI: $10.4141 /$ cjps 78-157.

10. Becker H.C. Correlation among some statistical measures of phenotypic stability. Euphytica. 1981. № 30(3). P. 835-884.

11. Gauch H.G., Zobel R.W. AMMI analysis of yield trials. Chap. 4. In: Kang, M.S. \& Gauch H.G., (Eds.), Genotype by environment interaction. CRC Press, Boca Raton, FL, USA. 1996. P. 85-122.

12. Purchase J.L., Hatting H., van Deventer C.S. Genotype $x$ environment interaction of winter wheat in south Africa : II. Stability analysis of yield performance. South African Journal of Plant and Soil. 2000. № 17. P. 101-107. DOI: 10.1080/02571862.2000.10634878.

13. Gauch H.G. Statistical analysis of yield trials by AMMI and GGE. Crop Science. 2006. № 46(4). P. 1488-1500.

14. Yan W. Singular-value partitioning in biplot analysis of multi-environment trial data. Agronomy Journal. 2002. № 94. P. 990-996. DOI: 10.2134/agronj2002.9900.

15. Yan W., Kang M.S. GGE biplot analysis: a graphical tool for breeders, geneticists and agronomists. Boca Raton, USA, 2003.

16. Gauch H.G.Jr, Piepho P.H, Annicchiarico P. Statistical analysis of yield trials by AMMI and GGE: further considerations. Crop Science. 200. № 48. P. 866-889.

17. Sabaghnia N., Dehghani H., Sabaghpour S.H. Nonparametric methods for interpreting GxE interaction of lentil genotypes. Crop Sci. 2006. № 46. P. 1100-1106.

18. Lin C.S., Binns M.R. A superiority measure of cultivar performance for cultivar $\mathrm{x}$ location data. Can. J. Plant Sci. 1988. № 68. P. 193-198.

19. Rose L.W., Das M.K., Taliaferro C.M. A comparison of dry matter yield stability assessment methods for small numbers of genotypes of Bermudagrass. Euphytica. 2008. № 164. P. 1925. DOI: $10.1007 / \mathrm{s} 10681-007-9620-2$

20. Akcura M., Kaya Y., Taner S., Ayranci R. Parametric stability analyses for grain yield of durum wheat. Plant Soil Environ. 2006. № 52 (6). P. 254-261.

21. Mohammadi R., Roostaei M., Ansari Y., Aghaee M., Amri A. Liens entre la mesure de la stabilite du phenotype et le genotype de trois cereals. Can. J. Plant Sci. 2010. № 90. P. 819830. DOI: $10.1139 / C J P S 2013-386$

22. Farshadfar E., Hatami N. Evaluation of Genotype $\times$ Environment Interaction in Wheat Substitution Lines. Agricultural Communications. 2015. № 3(1). P. 1-7.

\section{ПАРАМЕТРИЧНИЙ АНАЛІЗ СТАБІЛЬНОСТІ ВРОЖАЙНОСТІ ТВЕРДОЇ ПШЕНИЦІ (TRITICUM DURUM DESF)}

${ }^{1}$ Бенджама А., ${ }^{2}$ Солонечний П., ${ }^{3}$ Бузерцур Х., ${ }^{4}$ Рамдані С.

${ }^{1}$ Університет Скікда, Алжир

${ }^{2}$ Інститут рослинництва ім. В. Я. Юр'єва НААН, Україна

${ }^{3}$ Університет Сетіф 1, Алжир

${ }^{4}$ Університет Сіді-бель-Аббес, Алжир

Мета. Метою даних досліджень було визначити особливості взаємодії генотипсередовище (GEI) 23 генотипів твердої пшениці, використовуючи різні параметри стабільності для відбору генотипів, які мають як високу продуктивність, так і стабільність.

Матеріали та методи. Дослідження проводили у чотирьох пунктах випробування з різними грунтовими та гідротермічними умовами протягом 2008/092009/10 рр. Для кількісної оцінки стабільності врожаю було розраховано сім статистичних параметрів стабільності (bi, Pi, ASVi, CVi, $S^{2}$ di, $S^{2}$ i та $W^{2} i$ ).

Обговорення результатів. На врожайність зерна всіх генотипів суттєво вплинули умови вирощування, які обумовили 88,2 \% від загальної дисперсії врожайності, тоді як внесок 
фактору генотип та взаємодії генотип-середовище становив лише 2,9 \% та 8,9 \% відповідно. Середня урожайність досліджених генотипів мала значну позитивну кореляцію 3 коефіцієнтом регресії (bi) та дисперсією навколишнього середовища $\left(\mathrm{S}^{2} \mathrm{i}\right)$. Кореляційний аналіз також розділяв методи $\mathrm{Pi}$, bi та $\mathrm{S}^{2} \mathrm{i}$, які корелювали із середньою врожайністю, та методи $\mathrm{ASV}, \mathrm{W}^{2} \mathrm{i}$ та $\mathrm{S}^{2} \mathrm{di}$, які оцінювали фенотипову стабільність генотипів незалежно від врожайності.

Висновки. За результатами досліджень, генотипи Bel, Amg, Miki, Bss i Msb були найбільш стабільними за більшістю використаних статистичних моделей. Miki, Amg та Msb виділено як найкращі генотипи, що поєднували високі показники врожайності та високу стабільність у різних умовах.

Ключові слова: тверда пшениия, урожайність, генотип, стабільність, корелящія

\section{ПАРАМЕТРИЧЕСКИЙ АНАЛИЗ СТАБИЛЬНОСТИ УРОЖАЙНОСТИ ТВЕРДОЙ ПШШЕНИЦЫ (TRITICUM DURUM DESF)}

${ }^{1}$ Бенджама А., ${ }^{2}$ Солонечный П., ${ }^{3}$ Бузерзур Х., ${ }^{4}$ Рамдани С.

${ }^{1}$ Университет Скикда, Алжир

${ }^{2}$ Институт растениеводства им. В.Я. Юрьева НААН, Украина

${ }^{3}$ Университет Сетиф 1, Алжир

${ }^{4}$ Университет Сиди-бель-Аббес, Алжир

Целью исследования была оценка фенотипической стабильности 23 генотипов твердой пшеницы с использованием различных параметры стабильности для выделения генотипов, имеющих как высокую урожайность, так и стабильность.

Материалы и методы. Исследование проводили в четырех пунктах испытания с различными грунтовыми и гидротермическими условиями в течение 2008/09-2009/10 гг. Для количественной оценки стабильности урожая было рассчитано семь статистических параметров стабильности (bi, Pi, ASVi, CVi, $\mathrm{S}^{2} \mathrm{di}, \mathrm{S}^{2} \mathrm{i}$ и $\mathrm{W}^{2} \mathrm{i}$ ).

Обсуждение результатов. На урожайность зерна всех генотипов существенно повлияли условия выращивания, обуславливающие 88,2 \% от общей дисперсии урожайности, тогда как вклад фактора генотип и взаимодействия генотип-среда составил всего 2,9 \% и 8,9 \% соответственно. Средняя урожайность исследованных генотипов имела значительную положительную корреляцию с коэффициентом регрессии (bi) и дисперсией окружающей среды (S2i). Корреляционный анализ также разделял методы $\mathrm{Pi}$, bi и S2i, коррелирующие со средней урожайностью, и методы ASV, W2i и S2di, оценивающие фенотипическую стабильность генотипов независимо от урожайности.

Выводы. По результатам исследований генотипы Bel, Amg, Miki, Bss и Msb были наиболее стабильными по большинству использованных статистических моделей. Miki, Amg и Msb выделены как лучшие генотипы, сочетающие высокие показатели урожайности и высокую стабильность в различных условиях.

Ключевые слова: твердая пшеница, урожайность, генотип, стабильность, корреляция 


\section{PARAMETRIC STABILITY ANALYSIS OF DURUM WHEAT YIELD (TRITICUM DURUM DESF)}

${ }^{1}$ Bendjama A., ${ }^{2}$ Solonechnyi P., ${ }^{3}$ Bouzerzour H., ${ }^{4}$ Ramdani S.

${ }^{1}$ University of Skikda, Algeria

${ }^{2}$ Plant Production Institute nd. a V.Ya. Yuriev of NAAS, Ukraine

${ }^{3}$ University of Sétif 1 , Algeria

${ }^{4}$ University of Sidi Bel Abbes, Algeria

The study purpose was to assess the phenotypic stability of 23 durum wheat genotypes using different stability parameters to identify both high-yielding and stable genotypes.

Materials and methods. The study was carried out at 4 trial sites differing in soil and hydrothermal conditions in 2008/09 - 2009/10. To quantify the yield stability, 7 statistical parameters of the stability (bi, Pi, ASVi, CVi, S2di, S2i, and W2i) were calculated.

Results and discussion. The grain yields of all the genotypes were significantly affected by growing conditions, which accounted for $88.2 \%$ of the total variance of the yield, while the contributions of the genotype and genotype-environment interactions only amounted to $2.9 \%$ and $8.9 \%$, respectively. There were significant positive correlations between the average yield of the genotypes under investigation and the regression coefficient (bi) and between the average yield of the genotypes and the environment variance (S2i). Correlation analysis also separated $\mathrm{Pi}$, bi, and $\mathrm{S} 2 \mathrm{i}$ approaches that correlated with the average yield and ASV, W2i, and S2di approaches that evaluate the phenotypic stability of the genotypes regardless of the yield.

Conclusions. The results show that the genotypes Bel, Amg, Miki, Bss and Msb were the most stable by the majority of the statistical models used. Miki, Amg and Msb were distinguished as the best genotypes combining high yield and high stability under various conditions.

Key words: durum wheat, yield, genotype, stability, correlation

UDC 633.527:575

DOI

\section{ENVIRONMENTAL STABILITY AND PLASTICITY OF SPRING BARLEY CULTIVARS}

Vasko N.I., Solonechnyi P.M., Kozachenko M.R., Vazhenina O.E., Solonechna O.V., Naumov O.G., Zymogliad O.V.

Plant Production named after V.Ya. Yuriev of NAAS, Ukraine

The yields of spring barley cultivars harvested in 2008-2015 with contrast conditions were compared to determine the strength and direction of a cultivar response to weather conditions. Cultivars bred at the Plant Production named after V.Ya. Yuriev of NAAS were taken as the test material: Parnas, Ahrarii, Modern, Alehro, Dyvohliad, Schedryi (Experiment 1) - in 2008-2011; Avhur, Balzam, Grin, Modern (Experiment 2) - in 2013-2015. The yield data were statistically processed by ANOVA. The informative and differentiating capacity of the environments (years), as well as the breeding value of the cultivars, were determined by GGE biplot.

The study found that barley cultivars Parnas and Avhur fully exploited their potential under the favorable conditions of cultivation. They are intensive cultivars. Cultivars Alehro, Parnas,

(c) N.I. Vasko, P.M. Solonechnyi, M.R. Kozachenko, O.E. Vazhenina, O.V. Solonechna, O.G. Naumov, O.V. Zymogliad. 2019.

ISSN 1026-9959. Селекція і насінництво. 2019. Випуск 116. 